\title{
Anklav Turizm ve Gelişmekte Olan Destinasyonlar Üzerindeki Etkileri ${ }^{1}$
}

\author{
Enclave Tourism and Its Socio-Economic Impact in Emerging Destinations
}

\author{
Wineaster ANDERSON* \\ received 1 October 2011$)^{2}$ \\ Türkçeye Çevirenler: \\ Reyhan BOSTANCI**, Orkhan ALILI*** \\ **Öğretim Görevlisi, Yalova Üniversitesi, Armutlu Meslek Yüksekokulu, Armutlu, Yalova. \\ E-posta: reyhan.bostanci@yalova.edu.tr \\ ORCID: \\ ***Doktora Öğrencisi, İstanbul Üniversitesi, İktisat Fakültesi, 34116, Fatih, İstanbul. \\ E-posta: orxanalili@yahoo.com \\ ORCID:
}

*Wineaster Anderson University of Dar es Salaam, Department of Marketing, PO Box 35046, Dar es Salaam, Tanzania (Received 1 December 2010; final version

MAKALE BILGILERI

Anahtar sözcükler: Anklav turizm, Turist harcamaları, Gelişmekte olan destinasyonlar, Zanzibar.

ARTICLE INFO

Key words: Enclave tourism, Tourists expanditure, Emerging destinations, Zanzibar.

\section{ÖZ}

Bu çalıșma, gelișmekte olan destinasyonlarda anklav (Enclave)turizmin sosyo-ekonomik etkilerini araştırmak amacıyla yapılmıştır. Çalışmanın odak noktası olarak Zanzibar seçilmiştir. Araştırmanın amacı ise başta turistlerin toplam harcamalarının belirlenmesi olmak üzere, bu harcamaların demografik özelliklere göre farklılaşıp farklılasmadığını saptamak, ayrıca satın alınan paket tur kategorileri ile turistlerin harcamaları arasında istatistiksel farkııı̆ın olup olmadığını belirlemek üzere yapılmıştır. Veriler, 2009 yazında Zanzibar Havalimanında bulunan yabancı ziyaretçilere uygulanan spesifik bir anket aracılığı ile toplanmıştır. Verinin toplanmasından sonra turist harcamalarının akıșı ortalama vaka özetleri ile tahmin edilmiș, yapılan ANOVA ile de elde edilen ortalamaların birbirine eşit olup olmadığı test edilmiştir. Farklı kategorideki tur paketleri için yapılan harcamalar karşılaştıııldığında, Anklav Turizm kapsamında yapılan harcamaların diğer kategorilere göre daha az olduğu saptanmıștır. İstatistiksel kanıtlar, bu farkın temel olarak satın alınan paket tur çeșidinden kaynaklandığını, dolayısıyla da paket tur hizmetlerinin turistlerin günlük ortalama harcamaları üzerinde anlamlı bir etkiye sahip olduğunu ortaya koymaktadır. Araştırma, yoksul yanlı (pro-poor) turizmin yaygınlaşması için turizm endüstrisi ile yerel halk arasında bağlantı oluşturabilecek stratejiler önermesi açııından alanyazına katkı sağlamaktadır.

\section{ABSTRACT}

This study explores the socio-economic implications of enclave tourism in emerging destinations. The focus is on Zanzibar. The specific objectives are to estimate the gross tourist expenditure; to analyze the tourist expenditure in relation to the tourist demographic characteristics; and to find out whether there is any statistical difference between the expenditure caused by the type of the chosen tour mode. A specific visitor-survey was conducted at the Zanzibar Airport during the summer of 2009. Then, the flow of the tourist expenditure was estimated using aggregate-case summaries while the equality of the mean was analyzed using a one-way analysis of variance. Analysis of expenditure between the different categories of the tours reveals that the average daily expenditure spent by the enclave tourist was well below that made by the other types of contracts. There is statistical evidence to suggest that the differences were due to the chosen tour mode, as the type of tour has a significant effect on the average daily expenditure per tourist at the destination. The study recommends calculated strategies for linking the tourism industry with the local people for pro-poor tourism promotion.

\section{Gíriş}

Gelişen destinasyonlarda Anklav Turizm ve bu destinasyonlardaki olası sosyo-ekonomik sonuçları hakkındaki yazın yetersizdir ve genel olarak

${ }^{1}$ Bu yazı, Anderson, W. (2011). Enclave Tourism and Its Socio-Economic Impact In Emerging Destinations, Anatolia: An International Journal of Tourism and Hospitality Research, 22 (3): 361-377" künyesini taşıyan makaleden, izin alınarak çevrilmiştir. turizmin bu türü akademik camiada yeteri kadar dikkat çekmemiştir (Sheldon ve Mak 1987; Tourism Intelligence International 2005). Sheldon ve Mak (1987), paket tur talebi hakkında yeni ufuklar açan çalışmalarında Anklav Turizmi, sabit bir fiyata turistin kendi ülkesinde satın aldığ 1 ve ticari ulaşımdan konaklamaya, yeme-içmeye ve gezilecek yerleri görmeye kadar geniş ve çeşitli öğeleri kapsayan ve bazen bir tur lideri veya reh- 
ber eşliğinde yapılan bir geziler şeklinde açıklamaktadır. Tourism Intelligence International'in (2005) en son çalışmasında Anklav Turizm, ödemesi önceden yapılan, içinde turistin, seyahat ve turizm kapsamında ihtiyaç duyabileceği birtakım hizmetleri de barındıran bir gezi olarak tanımlamaktadır. Bu hizmetler genellikle gidiş-dönüş biletini, gidilen yerdeki transferleri, konaklamayı, tüm yeme içme faaliyetlerini, spor aktivitelerini, eğlenceyi, alışverişi ve diğer öğeleri içermektedir. Benzer tanımlamalar, Enoch (1996), Holloway $(1998,2000)$, Middleton (1994) ve Millington ve arkadaşları (2001) tarafından da yapılmıştır. Bu bağlamda 'gelişen destinasyonlar' konsepti turizm endüstrisinin hızla gelişen, emekleme döneminde ancak büyümekte olan destinasyonlara atıfta bulunmaktadır.

Çeşitli turist gruplarını kapsayan turizme dayalı ekonomilerin kıyaslamalarını yaparken, farklı grupların gelişen destinasyonlardaki Anklav Turizmin sosyo-ekonomik etkilerinin, özellikle yerel toplumlar açısından yoksulluğun azalmasına katkısının anlaşılabilmesi için önemlidir. Turistler, bazen Enoch'un (1996) koruyucu ebeveynler olarak nitelendirdiği tur operatörleri ve seyahat acentaları paketlerini önceden ödeme yaparak (Philips ve Webste 1983) satın almayı tercih ederler (Heung ve Chu 2000). Tatil köyleri, tur operatörlerinin genellikle turistin yaşadığ 1 ülkede bulunması, bütün görüşmeleri, lojistik hizmetleri ve misafirler ile finansal düzenlemeleri onların adına yapması sebebiyle Anklav Turizmi tercih ederler (Issa ve Jayawardena 2003; Karramel ve Lengefeld 2005; Mitchell ve Page 2005). Neredeyse her şey turistin yaşadığ $\breve{1}$ ülkede önceden tur operatörüne ödendiğinden (Heung ve Chu 2000; Philips ve Webster1983) bu gibi tatilleri sunan tatil köyleri turistlerin kayıtlarının ve faturalarının tutulması görevlerini de üzerlerinden atmaktadirlar. Bunlara ek olarak, tatil köyleri önceden misafir sayısını, profillerini ve kalış sürelerini öğrenebildiklerinden, gerekli olan satın alma işlemlerini daha net olarak tamamlayabilmektedir. Enoch'a (1996) göre, turistlerin ihtiyacı olabilecek hemen hemen her şey tedarik edildiğinden, genellikle günlerini Anklav tatil köylerinin sterilize edilmiş ortamında geçirmekte ve tesis dışındaki yerleri nadiren ziyaret etmektedirler. Reid (1992) tarafından "Dinlence Kampları" olarak tarif edilen bu tatil köyleri, konaklamadan ayrı olarak çeşitli yüzme havuzlarını, barları ve restoranları; özel plaj uzantılarını; peyzaj bahçelerini ve çeşitli spor tesislerini de içine alan bütünsel bir tatil deneyimi sunmaktadır (Millington vd. 2001).

Bütün bunların yanında, bu tür turizm ürününü sunan destinasyonlar bakımından Anklav Turizmin sosyo-ekonomik etkileri detaylı inceleme gerektiren sorunlara yol açar. İlk olarak, neredeyse her şeyin ödemesi turist gönderen ülkede tamamlandığından, turistler Anklav tatil köylerinin içinde kalmaya daha meyilli olurlar. $\mathrm{Bu}$ da onların destinasyondaki hareketlerini s1nırlandırmakta ve ödemesi önceden yapılmış tek tur paketinde dâhil edilmemiş ürünler için bile harcama yapma motivasyonlarını azaltmaktadır. Bundan dolayı, çoğu kişi gidiş dönüş uçak bileti dışındaki harcamalarının çoğunun turistlerin geldikleri ülkede kalıp gittikleri ülkeye yansımadığını düşünmektedir. (Freitag 1994; Abdool ve Carey 2004). Anklav Turizm aynı zamanda turistlerin yarım pansiyon gibi paketler satın alarak gidilen bölgede harcama yapabileceği turizm türlerini de sınırlandırmaktadır.

Bu durum Mbaiwa (2005) tarafından; turizmin geliştiği destinasyonlardaki çoğu Anklav tatil köylerinin sahiplerinin yabancılar olduğu hususundaki ortaya koyduğu bilgiyi hatırlatmaktadır. Bu bilgiye göre, turist harcaması ya alıkonmaktadır veya işte çalışanların yabancı ağırlıklı olması nedeniyle yabancı ülkeye geri dönmektedir. Zanzibar'da, çoğu otelin ve restoranın g1da gereksinimlerinin önemli bir miktarını ithal etmeleri özellikle ilgi çeken bir durum olmuştur. Zanzibar Turizm Yatırımcıları Birliğinin Raporu (2009) ve Steckve arkadaşlarına (2010) göre Zanzibar'daki yerel turistik otellerde ve restoranlarda tüketilen gıdaların \%90'lık kısmının ithal edilmektedir. Aynı zamanda, Meyer'e (2010) göre; Zanzibar'daki turizm sektöründe tüketilen bütün sebzelerin yaklaşık olarak \%80'lik kısmı ve bütün meyvelerin \%20'lik kısmı ithal edilmektedir. Anklav tatil köyleri ele alındığında, çoğu tatil köyünün gereksinimlerinin ne kadarını ithal ettiği, turistlerin içeride ne kadar süre kaldığı ve onların bazı ürünleri satın almasını sağlayacak yerel 
topluluklar ile etkileşimlerinin ne kadar sınırlandırıldığı, turizm altyapısı için ödenen vergilerdeki paranın yerel topluma ne kadar fayda sağladığı merak uyandırabilir.

Kabul edilmelidir ki, Anklav Turizm dünya genelinde kapsamlı şekilde büyümüştür (Mbaiwa 2005; Paris ve Zona-Paris 1999; Tourism Intelligence International 2005). Ne yazık ki, bu turizm türünün doğası ve onun doğurabileceği olası sosyo-ekonomik sonuçları turizm çalışmalarında göz ardı edilmeye çalışılmıştır. Bu sebeple, bu çalışma, gelişen destinasyonlarda Anklav Turizmin sosyo-ekonomik olası sonuçlarını araştırıp keşfetmek adına yapılmıştır. Bu araştırmanın amaçları üç bölümden oluşmaktadır: (a) turistlerin brüt harcamasını tahmin etmek; (b) turistlerin demografik özelliklerine göre harcamalarını analiz etmek ve (c) Zanzibar'ın seçilen tur türü bakımından sebep olunan herhangi bir istatistiksel farklılığın olup olmadığını ortaya çıkartmak üzerinedir. Sonuç olarak, politika oluşturucular ve turizm yöneticileri, Zanzibar'ı ziyaret eden farklı turist gruplarından destinasyonda turizm pastasının ne kadarının kaldığını öğrenmek isteyeceklerdir. Turizm harcamaları ekonominin çekirdeğidir ve turizm tedarikçileri için temel hedeftir. Bu sebeple, turizm tedarikçileri arasından dağılımın nasıl yapıldığını bilmek, politika yapılmasında ve bu politikaların hayata geçirilmesinde kılavuzluk edecektir. Çalışmanın amacının ortaya konulması için, öncelikle alanyazın gözden geçirilecek, sonra da çalışmanın metodolojisi açıklanacaktır. Sonrasında çalışma, bulguların değerlendirilmesi ve sonucun yazılması ile tamamlanacaktır.

\section{YAZIN TARAMASI}

Anklav Turizmin sosyo-ekonomik olası sonuçları üzerine yapılan çalışmaların büyük çoğunluğu Karayipler (Issa ve Jayawardena 2003; Abdool ve Carey 2004; Karammel ve Lengefeld 2005; Mitchell ve Page 2005; Ashley 2006; Meyer 2006) gibi gelişmiş destinasyonlarda yapılmıştır. Ancak bu alan gelişen destinasyonlarda ve özellikle gelişmekte olan ülkelerde yeterince araştırılmamıştır (Mbaiwa 2005). Sonuç olarak da bu alandaki yetersizlik nedeniyle bu tür çalışmaların yapılma- sı gerekliliğini ortaya çıkmıştır. Gelişmekte olan ekonomilerde turizm sektöründe karşılaşılan sorunların en bilinenleri; kötü altyapı, yetersiz ürün geliştirme ve yönetme, kötü ürün pazarlama, yerel ekonomi içinde eksik bağlantılar kurma, kötü şartlarda kurumsal ve teknik olanaklar ile alanında uzmanlaşmış, becerikli personelin yetersizliğinden oluşmaktadır (Mitchell 2006).

Turizm düzenlemeleri açısından gelişmekte olan ve gelişmiş ekonomiler arasında farklılıklar olduğu bir gerçektir. Talep perspektifinden, Anklav Turizm yabancı kültürler, güvenilmez ulaşım, hijyen standardı şüphesi, güvenlik ve emniyet zafiyetinden olduğu düşünülen ülkelerde özellikle tercih edilmektedir. Başka bir deyişle çoğunlukla gelişen destinasyonlarda yansıtılan koşullar ile ülkeleri seçerken turistlerde oluşan algılar, bu ana dürtülerin artması ile tercih sebebi olmuşlardır (Mbaiwa 2005). Tedarik tarafında, özellikle gelişmiş ülkelerde, tur operatörleri Anklav Turizmi toplu olarak yüksek gelir getirebilirliği açısından tercih etmektedirler (Tourism Intelligence International 2005).

Anklav Turizm düzenlemelerinin pek çok olası sonuçları vardır, fakat başlıca olası sonuçları arasında, turizm hizmet gruplarının, turist çeken ülkelerin ve turistlerin dâhil olduğu ana paydaşlar arasında ekonomik kazançların veya turizm harcamalarının birbirinden ayrılması gelmektedir. Turizm harcaması, bir ziyaretçi tarafından bir destinasyona yapilan gezi ve gezi sirasında yapılan toplam tüketim harcamasina atıfta bulunur (UNWTO 1994). 'Destinasyon' sözcüğü, bir gezi sırasında ziyaret edilen, dikkat çeken herhangi bir yer, alan olarak adlandırılmaktadır (WTO 2005). Sheldon (1990) turizm harcamasının, turistik alanlarda veya çalışma alanı dâhilinde turizm olmadan meydana gelmeyen tüketim olduğunu ileri sürmektedir. Anderson'a göre $(2008,2010)$ Anklav Turizm harcaması, bir destinasyonu ziyaret eden turistik gruplarca en azından geri dönüş ulaşımı, konaklaması, yeme içme faaliyetleri, eğlencesi ve ulaşımı açısından bulunduğu yerde tek bir fiyat uygulaması üzerinden önceden ödenmiş gezi masrafları olarak tanımlanmaktadır. Çoğu durumda turist, alışveriş, iletişim, araç ve ekipman kiraları ve diğer öğeler için destinas- 
yonlarda ek masraf harcamasını yapmaktadır.

Genellikle ziyaretçilerin geldikleri ülkelerde bulunan tur operatörleri, satılan turların ölçek ekonomileri vasıtasıyla daha fazla müşteri kazanmak için bir fiyatlandırma stratejisi olarak paket turları kullanmaktadır. Turist çeken ülkeler turizmi sadece kişi ve yatak sayısı için değil, aynı zamanda turizm kazançları için teşvik edici bir unsur olarak görmektedir. Bir turist, pahalı olmayan turlardan birini satın aldığında ve memnun ayrıldığında, tur operatörleri kârını, zaman ve para bakımından en üst seviyeye çıkartmak istemektedirler. Daha önce belirtildiği gibi turistlerin geldiği ülkenin ekonomisi, Anklav Turizm yapılan ülkenin ekonomisinden çok daha fazla kazanç sağlamaktadır (Wong ve Lau 2001; Issa ve Jayawardena 2003; Alegre ve Pou 2006). Anklav Turizm, tatil köyleri yarım pansiyon gibi paketlerle turistlerin başka yerlerde harcama yapmasını sağlayabilecek her türlü potansiyel harcamalarını içine alır. Gelişmekte olan ülkelerde olduğu gibi çoğu tatil köyüne yabancılar sahip olduğu için tatil köyüne giden harcamalar bile destinasyonda kalmayabilir.

Mbaiwa 2005 yılında Botsvana'daki Okavango Deltasında Anklav Turizmin sosyo-ekonomik etkisini araştırmak üzere bir çalışma yapmıştır. Çalışma, bölgedeki turizm tesislerinin yabancı hâkimiyetinin ve sahipliğinin (yabancılar turizm tesislerinin yarısından fazlasına $(\% 53,7)$ sahiptir) ortaya konulması amacıyla yapılmıştır. Sonuç olarak elde edilen gelirin turistlerin geldiği ülkeye geri döndüğü, yönetim pozisyonlarının hâkimiyetinin ülkede bulunan yabancılara geçtiği ve yerli çalışanların daha düşük maaşa çalıştırıldıkları sonuçlarına varılmıştır. Mbaiwa (2005)daha da ileri giderek Anklav Turizmi bir tür "dâhili kolonicilik" ile eşit tutar ve bunun yüksek kaçaklar nedeniyle Okavango Deltasında minimum etkiye sahip olduğu sonucuna varir. Buna benzer olarak, Anklav Turizmin tedarik yanına odaklanmada, Meyer (2006) Anklav Turizmin destinasyonda büyüyen mevcudiyeti nedeniyle yerel bağlantılarda olumsuz trendlerinin olduğunu ortaya çıkarmıştır. Bunun benzerine Abdool ve Carey' in (2004) Tobago'nun ekonomisi üzerine yaptığı Anklav Turizm sektörünün ekonomik etkisini araştıran çalışmasında rastlanmaktadır. Çalışmalarında, neredeyse her şeyin turistin kendi ülkesinde önceden ödendiğinden Anklav Turizm esaslı kisımlarının harcamalarının Tobago'nun ekonomisine katılmadığı ya da orada kalmadığı sonucunu ortaya çıkarmıştır.

Yaş, cinsiyet, gelir ve uyruk gibi sosyo-demografik değişkenler dinlenme ile ilgili harcamanın seviyesini açıklamak için turizm alanyazınında geniş bir şekilde araştırılmıştır. Açık bir şekilde, bir kişinin yaşı ile harcama davranışı arasındaki olumlu bir ilişki ortaya konulmuştur (Agulio ve Juaneda 2000; Mok ve Iverson 2000; Jang ve arkadaşları 2004; Kastenholz 2005). Yapılan çalışmada bir kişinin yaşlandıkça daha yüksek gelir kazanma eğiliminde olduğu ileri sürülmektedir ki bu da tatillerde daha fazla harcama yapma eğilimine yol açmaktadır. Bununla birlikte, Mudambi ve Baum (1997) yetişkin turistlerin Anklav Turizm için ana harcamasının, yeme-içme ve konaklama gibi gerekli mal ve hizmetlerin önceden ödenmiş olmasından tatilleri sırasında daha az harcama yaptıklarını ileri sürerek turistin harcaması ile yaşı arasındaki olumsuz ilişkiyi ortaya çıkarmıştır.

Sheldon ve Mak'a (1987) göre, bagaj taşıma ve destinasyondaki can sıkıcı hareketler gibi fiziksel faaliyetlerden sakınmak için yetişkin turistler anklav paket turları tercih etmektedir. Bu turistler, bu sebeple destinasyonda daha az harcama yapacakları tatil köylerinde tüm tatil boyunca konaklamayı tercih etmektedirler. Jang ve arkadaşları (2004), diğer taraftan, uyruk, eğitim ve meslek ile turist harcaması arasındaki ilişkide destinasyonda en yüksek harcama yapan turistlerin iyi eğitim sahibi kişiler ile idari işlerde çalışan, kredi kartlarını yüksek tercihler ile kullananlar kişiler olduğunu ortaya çıkarmıştır. Aynı zamanda gelir ile harcama arasında olumlu ilişkinin olduğuna dair benzer sonuçlara Peerapatdit (1999) ve Kastenholz 'un (2005) yaptığı çalışmalarda da ulaşılmıştır.

Destinasyonda belirli bir tur operatörü arac1lığıyla seyahat edilmesi ile harcama davranışı arasındaki ilişki test edilmiştir. Buna benzer örnekler, Rewtrakunphaiboon ve Oppewal (2004) ve Alegre ve Pou (2006) çalışmalarında, tur pa- 
ketlerinin destinasyonda harcama seviyesi için olumsuz etkisi olduğunu fakat bulunduğu yerde ise olumlu etkisi olduğunu meydana çıkartmıştır ve en düşük paketli turlar destinasyonda yüksek harcamaya yol açarken bu durumun tersi de olabileceği gözlenmiştir. Benzer şekilde, Mayorka'da Anklav Turizm müşterileri için belirleyici etkenleri incelerken, Anderson (2010) Mayorka'ya diğer tur paketleri ile seyahat eden turistleri kıyaslandığında, Anklav Turizmi tercih edenlerin destinasyonda daha az para harcadıkları sonucuna ulaşmıştır. Buna ek olarak, aynı destinasyonda Anklav Turizmi etkileyen motivasyonları inceleyen Anderson ve arkadaşları (2009), diğer tur çeşitlerine göre anklav turların tercih edilmesine etki eden faktörlerden birinin de ölçek ekonomisi olduğunu belirlemiştir.

Bununla birlikte, mevcut olan bilgiler daha çok gelişmiş ekonomilere odaklanmaktadır ve gelişmiş ekonomilerdeki anklav tatil köylerinin çoğu, müşterilerin bütün istek ve ihtiyaçlarına göre ürün ve hizmet hazırlamaktadır. Bu yüzden anklav tatil köyleri özellikle uzak alanlarda bulunmaktadır. Turistlerin daha çok tatil köylerinde harcama yapmalarına ortam hazırlamaktadır. Ayrıca turistlerin anklav tatil köylerinde harcama yapmalarının sağlanması ile destinasyonda ilave para harcamaların önüne geçileceği bir gerçektir (Abdool ve Carey 2004; Mbaiwa 2005). Anklav Turizm ürünü, her zaman tek bir duruma bağlı değildir. Ürünün bulunduğu konuma, ürünü sunan tatil köylerinin işlevlerine ve ziyaret edilen destinasyonun yapısına da bağlıdır. Karayipler'de anklav tatil köyleri bilinen destinasyonlarda birleştirilmiş tek bir ürün olarak ele alınırken destinasyonda sürekli yaşayanlardan da ayrı tutulmaya çalışılmıştır.

Karayipler'den farklı olarak, gelişen destinasyonlarda ve Zanzibar'da, anklav turlar normal olarak otelde sunulan pansiyon türlerinden biri olarak kabul edilmekte olup, buna ek olarak çoğu otel eş zamanlı olarak yarım pansiyon gibi diğer pansiyon türlerini de sunmaktadır. Anklav Turizmi seçen turistler için tur deneyiminin içeriği Karayipler'e göre daha hafif olduğundan, diğer ihtiyaçlarını ve isteklerini karşılamak isteyen turistler anklav tatil köylerinin dışına çıkmak zorundadırlar. Bu araştırmamamızda gelişen ve gelişmekte olan destinasyonları temsil etmek için Zanzibar seçilmiştir. Çalışmada elde edilen bulgular Anklav Turizm fenomeni üzerine önemli gerçeklerin ortaya çıkmasına yardımcı olmaktadır. Bununla birlikte, çalışmanın sonuçları kesin olmamakla birlikte, elde edilen sonuçlara ek olarak yapılacak araştırmalarda doğrulanmalıdır. Sonuç olarak, yapılan testler turizm pazarının objektif bilgi birikimine katkıda bulunmak için tasarlanmıştır. Takip eden bölüm çalışmanın yöntemini açıklamaktadır.

\section{YÖNTEM}

Bu çalışmanın amacı gelişmekte olan destinasyonlarda Anklav Turizmin sosyo-ekonomik etkilerinin araştırılmasıdır. Araştırmada veriler, 2009 yilında, yüksek sezon olarak nitelendirilen Haziran-Eylül ayları arasındaki dönemde Zanzibar Havalimanındaki yabancı ziyaretçilere uygulanan çıkış anketi ile toplanmaya çalışılmıştır. Araştırmada yabancı ziyaretçi çıkış anketlerinin tercih edilme sebebi bu anketler ile turist harcamalarına yönelik anlık ve güncel verilere erişimin sağlanmasıdır. Zanzibar'a yapılan seyahatlerin en az yarısı Mayıs-Ekim ayları arasındaki dönemde gerçekleşmekte olup, ada destinasyonu olmasından dolayı turistlerin \%80'nin havayolu ile ulaş1$\mathrm{m}$ tercih ettikleri görülmektedir. Bazı turistlerin yakın çevresi ile birlikte seyahat ediyor olmasından dolayı, bu şekilde ve benzer seyahat özelliklerini paylaşan grupları temsil etmek amacıyla araştırmada seyahat partisi (travel party) terimi kullanılmıştır. Araştırma örneklemini oluşturmada her deneğin örneklemde eşit oranda temsil edilmesi amaçlanmıştır. Araştırmaya toplam 2000 turist katılmıştır (0,03 örneklem hatası ve \%95 güven aralığı ile örneklem sayısı yeter sayı olarak kabul edilmiştir). Araştırma kapsamında dokuz sorudan oluşan anketin katılımcılar tarafından cevaplanması istenmiştir. Seyahat sürecinde satın alınan hizmetleri birbirinden ayırmak amaciyla aşağıdaki soruya ankette yer verilmiştir:

- Seyahatiniz kapsamında aşağıdaki hizmetlerden hangilerini kendi ülkenizde satın aldınız? Sorusu altında 6 seçenek sunulmuştur. Bunlar; 1) Sadece ulaşım 2) Ulaşım ve konaklama 3) Ulaşım, 
konaklama ve kahvaltı 4) Yarım pansiyon 5) Tam Pansiyon ve 6) Anklav seçenekleridir.

Ayrıca ankette; katılımcıların kaç kişi ile birlikte seyahat ettikleri, kalış süreleri, destinasyona yaptıkları seyahatlerin sayısı ile beraber milliyet, yaş, cinsiyet ve hane halkı geliri gibi diğer demografik özelliklerine ilişkin sorulara da yer verilmiştir. Turistlere tüm seyahatleri boyunca yaptıkları toplam harcama miktarı da sorularak; bu kapsamda hem geliş ülkesinde, hem destinasyonda (Zanzibar'da) yaptıkları harcamalar ile bu iki kalemin toplamına ilişkin verilere de ulaşmak amacryla ilgili ifadelere yer verilmiştir.

Araştırma örneklemi belirlenirken turistlerin herhangi bir karakteristik özelliği göz önünde bulundurulmadan Zanzibar'a gelen ziyaretçiler arasından tesadüfî örnekleme yöntemi ile seçim yapılmıştır. Toplamda 2000 turistin ankete katılımı sağlanmıştır. Katılımcıların \%9,2'si geliş ülkesinde sadece dönüş biletini, $\% 8,7^{\prime}$ si hem gidiş-dönüş bileti hem de konaklama hizmetlerini satın aldıklarını beyan ederken, bunlara ek olarak kahvaltıyı da alanların \%10,6, yarım pansiyon konaklamayı seçenlerin $\% 24,7$, tam pansiyon konaklamayı tercih edenlerin $\% 7,5$, anklav turlar ile gelen turistlerin ise toplam katılımciların \%38'ini oluşturdukları görülmektedir. Katılımcıların diğer özelliklerine ilişkin bilgiler Tablo 1'de özetlenmiştir.

Bu çalışmanın amacı, Zanzibar'ı ziyaret eden turistlerin yaptıkları toplam harcamaların belirlenmesi, turist harcamalarının ziyaretçilerin demografik özelliklerine göre farklılık gösterip göstermediğinin analiz edilmesi ve Zanzibar'a yapılan seyahatte satın alınan paket turların çeşidine göre yapılan harcamaların istatistiksel olarak anlamlı bir farklılığa sahip olup olmadıklarınin tespit edilmesidir. Veriler toplandıktan sonra hem geliş ülkesinde hem de Zanzibar'da yapılan harcamalar ve bunların toplam tutarları belirlenerek farklı kategoriler altında gruplandırılmıştır. Zanzibar'ı ziyaret eden turistlerin büyük bölümünün Avrupa ülkelerinden gelmesi sebebiyle anket sorularında para birimi olarak Euro kullanılmış, ardından cari döviz kuru üzerinden bu tutarlar dolara dönüştürülerek tahminler yapılmaya çalışılmıştır.

Seçilen paket turun çeşidine göre hem turist ba- şına hem de günlük olarak yapılan ortalama harcamalar arasında anlamlı bir farkın olup olmadiğını belirlemek amacıyla tek yönlü varyans analizi (oneway ANOVA) uygulanmıştır. Kurulan hipotez farklı demografik özelliklere sahip turistlerin yaptıkları ortalama harcamalar arasında anlamlı bir farklılığın bulunduğunu doğrular niteliktedir. Bu bakımdan, araştırma kapsamında kurulan $\mathrm{H}_{0}$ hipotezi Zanzibar'ı ziyaret eden turistler için yapılan harcama ortalamalarının birbirine eşit olduğunu, $\mathrm{H}_{1}$ hipotezi ise yapılan harcamalar arasında anlamlı bir farkın var olduğunu göstermektedir. Bu bakımdan paket tur kapsamında satın alınan hizmetleri (sadece ulaşım; ulaşım ve konaklama; ulaşım, konaklama ve kahvaltı; ulaşım ve yarım pansiyon konaklama; ulaşım ve tam pansiyon konaklama; Anklav Turizm) ele alalım. Örneğin, Zanzibar'ı anklav turlar kapsamında ziyaret eden turistlerin genç (26-44 yaş arasında) ve diğer kategorideki turistlerin tamamindan daha az harcama yapan turistler olduklarını varsayarsak, bu turların tercih sebebinin ziyaretçilerin genç olmasından kaynaklandığına yönelik tahmin yürütülebilir. Ancak diğer turlarla karşılaştırdığımızda bu farkın neden kaynaklandığını ortaya çıkarmak amacıyla ikiden fazla değişkenin analize tabi tutulduğu ANOVA kullanilabilir. Bu kapsamda kukla değişkenlerden yararlanılarak regresyon modelinin oluşturulmasına da gerek duyulacaktır.

Örneğin, ziyaretçilerin sadece anklav veya sadece konaklamalı turlar ile Zanzibar'a geldiklerini ve gelen ziyaretçilerin $26-44$ yaş ve $45-65$ yaş olmak üzere sadece iki yaş aralığında sinıflandırıldıklarını varsayalım. Turizm harcamaları devamlı değişkenler olup, her gruptaki ortalama harcamaları tahmin etmek ve farklılıkları karşılaştırmak için aşağıdaki lineer model kurulabilir:

$$
\mathrm{Y}_{\dot{\mathrm{I}}}=\beta_{\mathrm{i}}+\beta_{1} \mathrm{D}_{1 \mathrm{i}}+\beta_{2} \mathrm{E}_{1 \mathrm{i}} \mathrm{E}_{1 \mathrm{i}}
$$

Burada:

$$
\mathrm{D}_{1 \mathrm{i}}=0=\text { Anklavturlar }
$$

$1=$ Konaklamalı turlar

$\mathrm{E}_{1 \dot{\mathrm{I}}}=0=26-44$ yaş arası ziyaretçiler

$1=45-65$ yaş arası ziyaretçiler 
Kurulan model, yaş değişkeni bakımından hem arttırıcı, hem de çarpımsal etkiler ile ilişkilendiTablo 1. Katılımcıların Karakteristik Özellikleri

\begin{tabular}{|c|c|c|c|c|c|c|c|}
\hline Özellikler & $\begin{array}{l}\text { Sadece } \\
\text { Ulaşım }\end{array}$ & $\begin{array}{c}\text { Konaklama } \\
\text { dahil }\end{array}$ & $\begin{array}{c}\text { Kahvaltı } \\
\text { dâhil }\end{array}$ & $\begin{array}{c}\text { Yarim } \\
\text { Pansiyon }\end{array}$ & $\begin{array}{c}\text { Tam } \\
\text { Pansiyon }\end{array}$ & $\begin{array}{c}\text { Anklav } \\
\text { tur }\end{array}$ & Toplam \\
\hline \multicolumn{8}{|l|}{ Yaş } \\
\hline 25 altında & 10,2 & 11,1 & 12,4 & 35,7 & 8,3 & 22,3 & 100,0 \\
\hline $26-44$ & 10,2 & 9,9 & 13,7 & 31,0 & 8,2 & 26,9 & 100,0 \\
\hline $45-64$ & 12,0 & 6,6 & 11,2 & 22,6 & 11,0 & 36,7 & 100,0 \\
\hline 64 üzeri & 4,6 & 7,6 & 4,1 & 9,8 & 1,8 & 72,1 & 100,0 \\
\hline Toplam & 9,4 & 8,7 & 10,7 & 24,9 & 7,5 & 38,8 & 100,0 \\
\hline \multicolumn{8}{|l|}{ Cinsiyet } \\
\hline Kadın & 7,9 & 9,9 & 9,2 & 26,4 & 7,2 & 39,3 & 100,0 \\
\hline Erkek & 10,9 & 7,6 & 12,4 & 23,4 & 7,7 & 37,9 & 100,0 \\
\hline Toplam & 9,4 & 8,8 & 10,8 & 25,0 & 7,5 & 38,6 & 100,0 \\
\hline \multicolumn{8}{|l|}{ Milliyet } \\
\hline İspanyol & 4,6 & 6,6 & 6,4 & 24,0 & 3,6 & 54,9 & 100,0 \\
\hline İtalyan & 16,8 & 11,6 & 14,4 & 20,7 & 8,2 & 28,4 & 100,0 \\
\hline Alman & 4,5 & 8,1 & 8,1 & 45,7 & 8,1 & 25,3 & 100,0 \\
\hline Frans1z & 4,4 & 2,6 & 4,4 & 24,4 & 2,0 & 62,1 & 100,0 \\
\hline Britanyalı & 1,5 & 3,3 & 4,5 & 37,3 & 16,4 & 37,0 & 100,0 \\
\hline Diğer & 3,3 & 12,6 & 17,6 & 13,2 & 11,0 & 42,3 & 100,0 \\
\hline Toplam & 9,4 & 8,8 & 10,8 & 25,0 & 7,5 & 38,6 & 100,0 \\
\hline \multicolumn{8}{|c|}{ Kalış süresi (Gün ile) } \\
\hline $1-7$ & 13,2 & 6,6 & 12,3 & 25,9 & 10,4 & 31,6 & 100,0 \\
\hline $8-14$ & 6,9 & 9,2 & 13,8 & 28,2 & 7,9 & 34,1 & 100,0 \\
\hline $15-21$ & 9,7 & 9,3 & 8,1 & 23,5 & 6,1 & 43,4 & 100,0 \\
\hline $21-28$ & 10,8 & 8,4 & 9,0 & 22,2 & 7,6 & 42,1 & 100,0 \\
\hline Toplam & 9,4 & 8,7 & 10,8 & 25,1 & 7,6 & 38,5 & \\
\hline \multicolumn{8}{|l|}{ Gelir (Euro) } \\
\hline 20,000 altı & 7,6 & 10,8 & 7,3 & 27,5 & 10,5 & 36,3 & 100,0 \\
\hline $20,000-30,000$ & 5,5 & 10,6 & 4,7 & 22,9 & 8,6 & 47,6 & 100,0 \\
\hline $30,001-40,000$ & 4,2 & 3,1 & 11,8 & 28,1 & 7,6 & 45,1 & 100,0 \\
\hline $40,001-50,000$ & 13,6 & 5,1 & 16,9 & 22,0 & 9,6 & 32,8 & 100,0 \\
\hline $50,001-60,000$ & 10,1 & 10,8 & 12,7 & 21,5 & 5,1 & 399 & 100,0 \\
\hline 60,000 üzeri & 15,6 & 10,2 & 18,0 & 21,7 & 4,7 & 298 & 100,0 \\
\hline Toplam & 8,6 & 8,8 & 10,5 & 24,2 & 8,0 & 399 & \\
\hline \multicolumn{8}{|c|}{ Zanzibar'a önceki seyahatler } \\
\hline Hiç & 8,0 & 10,3 & 10,9 & 25,6 & 7,3 & 37,9 & 100,0 \\
\hline Bir kez & 6,8 & 10,5 & 13,9 & 22,4 & 6,3 & 40,0 & 100,0 \\
\hline İki kez & 11,4 & 9,8 & 11,7 & 16,7 & 8,3 & 42,0 & 100,0 \\
\hline Üç kez & 5,8 & 6,4 & 7,7 & 34,0 & 10,9 & 35,3 & 100,0 \\
\hline Dört kez & 7,2 & 5,8 & 2,9 & 24,6 & 7,2 & 52,2 & 100,0 \\
\hline 4'den fazla & 16,9 & 3,5 & 8,5 & 28,9 & 7,4 & 34,9 & 100,0 \\
\hline Toplam & 9,3 & 8,8 & 10,7 & 24,9 & 7,6 & 38,7 & 100,0 \\
\hline
\end{tabular}

rilmektedir. Bu bakımdan modeldeki $\beta_{0}$ referans grubunun yaptığı harcamaları göstermektedir ki, 
bu örneğimizde 26-44 yaş arasında ve Anklav Turizme katılan turistler bu gruba dâhil edilmiştir.

Buradaki $\beta_{\mathrm{J}}(j \neq 0)$ değeri, referans grubundan daha farklı özelliklere sahip turistlerin harcamalarında ortaya çıkan artışı (veya azalışı) gösteren değer olarak yorumlanabilir. Böylece modelin $\beta_{\mathrm{J}}$ katsayısı belirlendikten sonra, anklav veya konaklamalı turlara katılan turistlerin yaptıkları ortalama harcamaları belirlemek mümkün olacaktır. Yukarıdaki açıklamalardan yola çıkarak, Zanzibar'a anklav tur ile gelen, 26-44 yaş aralığındaki turistlerin yaptıkları ortalama harcamalar aşağıdaki şekilde hesaplanacaktır (Bu zaman; $\mathrm{D}_{1 \mathrm{i}}$ $=0$ ve $E_{1 i}=0$ olarak kabul edilecektir).

$$
\mathrm{Y}_{00}=\beta_{0}
$$

Bu durumda, anklav tur ile seyahat eden 44-66 yaş aralığındaki turistlerin ortalama harcamaları ise $\left(D_{1 \mathrm{i}}=0\right.$ ve $E_{1 \mathrm{i}}=1$ olarak kabul edilecektir);

$$
\mathrm{Y}_{01}=\beta_{0}+\beta_{2}
$$

Şeklinde hesaplanacaktır. Bu ikisinden yola çıkarak, her iki yaş grubunun anklav turlar ile Zanzibar'da yaptığı ortalama harcamalara ilişkin hesaplama aşağıdaki şekilde olacaktır:

$$
\mathrm{Y}_{0}=\left(\mathrm{Y}_{00}+\mathrm{Y}_{01}\right) \beta 0+\frac{1}{2} \beta_{2}
$$

Yukarıdaki denklem farklı türlerde paket turlar satın alan ve faklı demografik özelliklere (yaş, cinsiyet vs.) sahip turistlerin yaptıkları ortalama harcamaları hesaplamak amacıyla da kullanılabilmektedir. Bu çalışma kapsamında yapılan analiz sonucunda ortaya çıkan bulgular ise bir sonraki bölümde açıklanmıştır.

\section{BULGULAR}

Ziyaretçilerin yaptıkları ortalama harcamalar geliş ülkesinde satın alınan tur çeşitlerine göre; "sadece ulaşım", "ulaşım ve konaklama", "ulaşım-konaklama- kahvaltı", "ulaşım ve yarım pansiyon", "ulaşım ve tam pansiyon" veya "anklav tur" kategorilerinde gruplandırılmıştır. Ortalama harcamalara ilişkin verilere Tablo 2, Tablo 3, Tablo 4'de ve Şekil 1'de yer verilmiştir. Bu tablolarda yer alan ortalamalar marjinal ortalamalar olup, ortalama kalış süresi ve seyahat partisi büyüklüğü göz önünde bulundurularak hesaplanmıştır (Ortalama kalış süresi 9,32 gün olup, her seyahat partisinde ortalama dört kişi yer almaktadır). İstatistiksel sonuçlar önceki bulguları destekler nitelikte olup, anklav turları diğer tur modelleri ile karşılaştırdığımızda aşağıdaki sonuçlar elde edilmiştir;

a) Zanzibar'da ortalama kalış süresi 9,32 gün olup, gruptaki ortalama kişi sayısı dört kişidir.

b) Turist başına yapılan ortalama günlük harcama 119,09 Dolar olup; geliş ülkesinde ortalama harcama 79,76 Dolar iken, Zanzibar'da ise turist baş1na yapılan ortalama harcama 28,92 Dolar'dır.

c) Beklendiği üzere, anklav tur ile gelen turistler, geliş ülkesinde diğer tur çeşitlerine göre daha fazla harcama yapmaktadırlar.

d) Anklav tur ile gelen turistlerin geliş ülkesinde

Tablo 2. Geliş ülkesinde turistlerin ortalama günlük harcama miktarı

\begin{tabular}{lccc}
\hline $\begin{array}{l}\text { Geliş ülkesinde ödemesi } \\
\text { yapılan hizmetler }\end{array}$ & Ortalama Harcamalar & $\begin{array}{l}\text { Anklav tur ile karşılaştırlldı̆̆ında } \\
\text { yapılan ortalama harcama }\end{array}$ & $\begin{array}{l}\text { Anklav tur ile karşılaştırıldığında yapı- } \\
\text { lan harcamalar ile aradaki faiz farkı }\end{array}$ \\
\hline Sadece Ulaşım & 38,68 & 38,75 & $-61,25$ \\
Konaklama dâhil & 70,68 & 70,80 & $-29,20$ \\
Kahvaltı dâhil & 65,66 & 65,77 & $-34,23$ \\
Yarım Pansiyon & 76,00 & 76,13 & $-23,87$ \\
Tam Pansiyon & 86,72 & 86,87 & $-13,13$ \\
Anklav tur & 99,83 & 100,00 & - \\
Toplam & 79,76 & 79,90 & $-20,10$ \\
\hline
\end{tabular}

8 - Anatolia: Turizm Araştırmaları Dergisi 
Tablo 3. Zanzibar'da turistlerin ortalama günlük harcama miktarı

\begin{tabular}{lccc}
\hline $\begin{array}{l}\text { Geliş ülkesinde ödemesi } \\
\text { yapılan hizmetler }\end{array}$ & $\begin{array}{l}\text { Ortalama } \\
\text { Harcamalar }\end{array}$ & $\begin{array}{l}\text { Anklav tur ile karşılaştırıldı̆̆ında } \\
\text { yapılan ortalama harcama }\end{array}$ & $\begin{array}{l}\text { Anklav tur ile karşılaştırıldı̆̆ında } \\
\text { yapılan harcamalar ile aradaki faiz } \\
\text { farkı }\end{array}$ \\
\hline Sadece Ulaşım & 48,70 & 234,25 & 134,25 \\
Konaklama dâhil & 38,16 & 183,55 & 83,55 \\
Kahvaltı dâhil & 36,10 & 173,64 & 73,64 \\
Yarım Pansiyon & 30,34 & 145,94 & 45,94 \\
Tam Pansiyon & 28,96 & 139,30 & 39,30 \\
Anklav tur & 20,79 & 100,00 & - \\
Toplam & 28,92 & 139,11 & 39,11 \\
\hline
\end{tabular}

yaptıkları harcamaları, yarım ve tam pansiyon turlarla gelen turistlerin geliş ülkesindeki harcamaları ile kıyasladığımızda aradaki farkın yüksek olmadığ 1 görülmektedir. Bu bakımdan, anklav tur ile gelen ziyaretçiler ile karşılaştırıldığında, tam pansiyon konaklayan turistlerin geliş ülkesinde \%13 oranında, yarım pansiyon konaklayan turistlerin ise $\% 24$ oranında daha az harcama yaptıkları görülmektedir.

e) Anklav tur ile gelen turistlerin Zanzibar'da yaptıkları harcamaların diğer paket tur çeşitlerinin çok daha altında olduğu görülmektedir. Bu bakımdan, anklav tur ile gelen turistler tam pansiyon olarak konaklayan turistlere göre Zanzibar'da \% 39,30, yarım pansiyon olarak konaklayan turistlere göre ise $\% 45,94$ oranında daha az harcama yaptıkları görülmektedir. Bu bakımdan, anklav tur ile gelen turistlere göre tam pansiyon konaklayanların Zanzibar'da ortalama günlük 8,17 Dolar, yarım pansiyon konaklayanların ise ortalama günlük 9,95 Dolar daha fazla harcama yaptıkları görülmektedir.

f) Hem geliş ülkesinde hem de Zanzibar'da yapılan toplam harcamalar açısından anklav turu tercih eden turistlerin yaptıkları harcamaları diğer tur çeşitleri ile karşılaştırdığımızda, geliş ülkesinde sadece ulaşım hizmeti satın alan ziyaretçilerin toplam harcamalar bakımından en az harcama yapan grup oldukları görülmektedir. (Bu bakımdan, geliş ülkesinde sadece ulaşım hizmeti satın alan turistlerin toplam harcamalarının ortalama 87,38 dolar olduğu ve anklav tur ile gelen ziyaretçilere göre \%21,08 oranında daha az harcama yaptıkları görülmektedir). Toplam harcamalar bakımından tam pansiyon konaklayan turistlerin anklav tur ile gelen turistlere göre $\% 8,94$ oranında, yarım pansiyon konaklayan turistlerin \%14,11 oranında daha fazla harcama yaptıkları görülmektedir. Ayrıca, kahvaltı dâhil pansiyon ile gelenlerin \%0,94 oranında, sadece konaklama ve ulaşım hizmetleri satın alarak gelen turistlerin ise anklav tur ile gelen turistlere göre $\% 7,33$ oranında daha fazla harcama yaptıkları görülmektedir.

\section{Zanzibar’a Yapılan Tur Çeşidine Göre Turist Harcamalarının Analizi}

Zanzibar'ı ziyaret eden turistlerin yaptıkları ortalama toplam harcama 119 Dolar iken (Tablo 5), anklav turlar ile gelen turistlerin harcamalarının ortalamadan $\% 7,56$ oranında daha az olduğu belirlenmiştir. Yapılan ortalama toplam harcamalar açısından değerlendirdiğimizde, anklav turlar ile gelen turistlerin geliş ülkesinde yaptıkları harcamalar ortalamadan $\% 20,10$ daha fazla iken, destinasyonda ise yapilan ortalama toplam harcamalardan \%39,11 daha az olduğu görülmektedir. Yapılan harcamalar bakımından değerlendirildiğinde, anklav turlar ile gelen turistlerin yaptıkları harcamaların diğer tur çeşitlerinin çok daha altında olduğu tespit edilmiştir. Bunun temel sebebi, daha az hizmetin dâhil olduğu turu satın alan ziyaretçilerin geliş ülkesinde ödedikleri fiyatlara bu hizmetlerin dâhil olmaması ve bu hizmetleri varış ülkesinde satın almalarının zorunluluğudur (Örneğin konaklama fiyatları bakımından değerlendirdiğimizde, ilk kategoride yer alan turistler geliş ülkesinde sadece tek yön uçak bileti satın almışlardır).Turistlerin varış ülkesinde harcamalarının kategorilere göre farklılaşmasına ilişkin 
Tablo 4. Toplam turist başına günlük ortalama harcama miktarı

\begin{tabular}{lccc}
\hline $\begin{array}{l}\text { Geliş ülkesinde ödemesi } \\
\text { yapılan hizmetler }\end{array}$ & Ortalama Harcamalar & $\begin{array}{l}\text { Anklav tur ile kıyaslamada ortala- } \\
\text { ma harcama }\end{array}$ & $\begin{array}{l}\text { Anklav tur ile karşılaştırıldı̆̆ında yapılan } \\
\text { harcamalar ile aradaki faiz farkı }\end{array}$ \\
\hline Sadece Ulaşım & 87,38 & 78,92 & $-21,08$ \\
Konaklama dâhil & 118,84 & 107,33 & 7,33 \\
Kahvaltı dâhil & 111,76 & 100,94 & 0,94 \\
Yarım Pansiyon dâhil & 126,34 & 114,11 & 14,11 \\
Tam Pansiyon dâhil & 120,62 & 108,94 & 8,94 \\
Anklav tur & 110,72 & 100,00 & 0,00 \\
Toplam & 119,09 & 107,56 & 7,56 \\
\hline
\end{tabular}

veriler bir sonraki “Zanzibar'da turist harcamalarının izlenmesi" başlığı altında incelenmiştir.

Kurulan hipotez, tur çeşidine bakılmaksızın turist başına yapılan günlük harcama ortalamalarının birbirine eşit olacağını varsaymaktadır. Bu nedenle, yapılan harcama ortalamaları arasındaki farklılığın istatistiksel olarak anlamlı olup olmadığını analiz etmek, yapılan harcamalar arasında anlamlı bir farklılığın olması durumunda bunun

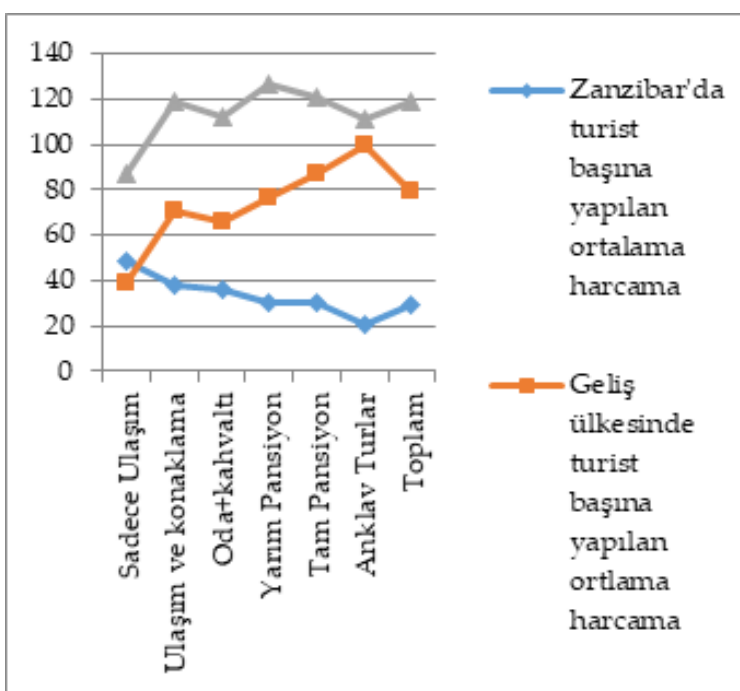

Şekil 1. Turist başına yapılan ortalama harcamalar

tesadüfi olarak mı ortaya çıktığ 1 veya turistlerin satın aldıkları tur çeşidinden mi kaynaklandığını ortaya çıkarması açısından son derece önemlidir. Daha önce de belirtildiği gibi bu çalışma turist başına yapılan günlük harcama ortalamaları arasinda anlamlı bir farklılığın bulunmadığını $\mathrm{H}_{0}$ hipotezi ile test etmekte iken $\left(\mathrm{H}_{0}=\gamma_{1}=\gamma_{2}=\gamma_{3}=\right.$ $\left.\gamma_{4}\right)$, alternatif hipotez ortalamaların birbirine eşit olmadığını ortaya koymakta olup, bu farkın han- gi gruplar arasında olduğu ANOVA ile belirlenmeye çalışılmıştır.

Tablo 6'daki ANOVA sonuçları üç grup arasında; toplam harcamalar, geliş ülkesinde yapılan harcamalar ve Zanzibar'da yapilan harcamalar arasında anlamlı bir farklılığın bulunduğunu ortaya koymaktadır. Bu bakımdan p değeri 0,000 çıkmış olup, böylece $\mathrm{H}_{0}$ hipotezi yani ortalamaların birbirine eşit olduğunu varsayan hipotez reddedilmekte ve altı farklı tur kategorisinde her bir turistin (örneğin geliş ülkesinde sadece gidişdönüş uçak bileti alan turistler ile uçak biletine ek olarak konaklama, kahvaltı, yarım pansiyon, tam pansiyon veya anklav tur hizmetlerinden de yararlananlar gibi) yaptıkları günlük ortalama harcamalar arasında anlamlı bir farkın var olduğunu ortaya çıkmaktadır. Bu da seçilen turun geliş ülkesinde, Zanzibar'da ve toplam harcamalar üzerinde anlamlı bir etkiye sahip olduğunu ortaya koymaktadir.

\section{Turist Harcamalarının Demografik Özelliklere Göre Analizi}

Tablo 7'de de görüldüğü üzere, ziyaretçilerin milliyetleri göz önünde bulundurularak yapılan analiz sonucunda ortalama harcama 110 Euro olup, 80 Euro geliş ülkesinde yapılmaktayken, geriye kalan 30 Euro ise Zanzibar'da yapilmaktadır. Özellikle, tüm kategorilerde İspanyol turistlerin çok daha az harcama yaptıkları ve toplam harcamalara göre \%11, geliş ülkesindeki harcamalara göre \%7,9 ve Zanzibar'daki harcamalara göre ise \%20 oranında daha az harcama yaptıkları görülmektedir. Diğer milliyetten olan ziyaretçilerin ise toplamda \%60, geliş ülkesinde $\% 76$, 
Tablo 5. Satın alınan tura göre turist başına ortalama günlük harcamalar

\begin{tabular}{lccr}
\hline Turist başına ortalama harcamalar (Amerikan Doları ile) & & & \\
Geliş ülkesinde ödemesi yapılan hizmetler & Toplam & Gelişülkesinde & \multicolumn{2}{c}{ Zanzibar'da } \\
\hline Sadece Ulaşım & 87,38 & 38,68 & 48,70 \\
Konaklama dâhil & 118,84 & 70,68 & 38,16 \\
Kahvaltı dâhil & 111,76 & 65,66 & 36,10 \\
Yarım Pansiyon dâhil & 126,34 & 76,00 & 30,34 \\
Tam Pansiyon dâhil & 120,62 & 86,72 & 28,96 \\
Anklav tur & 110,72 & 99,83 & 20,79 \\
Toplam & 119,09 & 79,76 & 28,92 \\
\hline
\end{tabular}

Tablo 6. ANOVA sonuçları (Tur çeşidine göre turist başına yapılan ortalama günlük harcamalar)

\begin{tabular}{|c|c|c|c|c|c|}
\hline & Kareler Toplamı & $\mathrm{df}$ & Ortalamalar Karesi & $\mathrm{F}$ & Sig. \\
\hline \multicolumn{6}{|l|}{ Tamamı } \\
\hline Gruplar arasında & 4224,64 & 837 & 5,05 & 4,37 & 0,00 \\
\hline Grup içinde & 1251,29 & 1084 & 1,15 & & \\
\hline Toplam & 5475,93 & 1921 & & & \\
\hline \multicolumn{6}{|l|}{ Geliş ülkesinde } \\
\hline Gruplar arasında & 3753,71 & 631 & 5,95 & 4,46 & 0,00 \\
\hline Grup içinde & 1722,22 & 1290 & 1,34 & & \\
\hline Toplam & 5475,93 & 1921 & & & \\
\hline \multicolumn{6}{|l|}{ Zanzibar'da } \\
\hline Grupları arasında & 2350,61 & 353 & 6,66 & 3,32 & 0,00 \\
\hline Grup içinde & 3221,65 & 1608 & 2,00 & & \\
\hline Toplam & 5572,26 & 1961 & & & \\
\hline
\end{tabular}

Zanzibar'da ise $\% 22$ daha fazla harcama yaptıkları görülmektedir.

Araştırma sonucunda elde edilen ilgi çekici bulgulardan biri, ziyaretçilerin yaşlarının artması ile destinasyonda yapılan harcama miktarının azalmasına ilişkindir. Bu bakımdan, yaşı 45'in altında olan ziyaretçilerin daha yaşlı turistlere göre destinasyonda daha fazla zaman geçirmeye istekli oldukları görülmektedir. Bunun altında yatan temel sebebin ise genç ziyaretçilerin anklav tur satın alsalar bile destinasyonda partilere, gece hayatı etkinliklerine, sportif faaliyetlere katılma eğiliminin yaşlı nesile göre çok daha yüksek olmasından kaynaklanabileceği ifade edilmiştir. Cinsiyet kategorisi bakımından değerlendirildiğinde, bu üç kategoride erkeklerin harcama yapmaya daha fazla istekli oldukları, bu bakımdan ortalama günlük harcamaların \%4 daha üstünde harcama gerçekleştirdikleri görülmemektedir. Ancak şunu da belirtmek gerekmektedir ki, har- cama davranışları yıllık toplam hane halkı gelirlerini göz önünde bulundurmadan analiz edilmesinden dolayı çıkan sonuçlar farklılık da gösterebilecektir.

Yapılan ilk ANOVA ile milliyet, yaş, gelir grubu ve cinsiyet gibi kategorik değişkenlere göre turistlerin harcama davranışlarının anlamlı bir şekilde birbirinden ayrılıp ayrılmadığ 1 belirlenmeye çalışılmıştır. Tablo 8'deki ANOVA sonuçları, bu dört demografik grubun kendi içerisinde anlamlı bir şekilde farklılaştı̆̆ını ortaya koymaktadır. Ayrıca, yaşa göre harcama davranışlarının $\% 95$ düzeyinde $(\mathrm{F}(1,1624)=3.85, \mathrm{p}=0.000)$ anlaml olduğu da ortaya çıkmıştır. Benzer şekilde, cinsiyet, milliyet, gelir değişkenlerinin de $p$ değeri anlamlı olup, bu dört değişkenin ziyaretçilerin destinasyonda yaptıkları harcamaların belirlenmesinde büyük bir etkiye sahip oldukları görülmektedir. 
Tablo 7. Turistlerin karakteristik özelliklerine göre turist başına yapılan ortalama harcamalar

\begin{tabular}{|c|c|c|c|}
\hline Ziyaretçilerin karakteristik özellikleri & Toplam & Geliş Ülkesi & Zanzibar \\
\hline \multicolumn{4}{|l|}{ Milliyet } \\
\hline İspanyol & 98,38 & 73,41 & 24,42 \\
\hline İtalyan & 99,80 & 66,99 & 32,53 \\
\hline Alman & 109,31 & 76,98 & 32,17 \\
\hline Frans1z & 130,27 & 103,90 & 26,37 \\
\hline Britanyalı & 131,40 & 99,24 & 31,66 \\
\hline Diğer & 177,24 & 140,35 & 37,03 \\
\hline Toplam & 110,45 & 79,73 & 30,39 \\
\hline \multicolumn{4}{|l|}{ Yaş } \\
\hline$\leq 25$ & 100,54 & 65,84 & 34,49 \\
\hline $26-44$ & 109,84 & 77,64 & 31,46 \\
\hline $45-64$ & 122,08 & 90,52 & 30,46 \\
\hline$>64$ & 104,98 & 80,78 & 23,42 \\
\hline Toplam & 110,39 & 79,72 & 29,88 \\
\hline \multicolumn{4}{|l|}{ Cinsiyet } \\
\hline Kadın & 105,58 & 77,24 & 27,21 \\
\hline Erkek & 111,98 & 81,64 & 29,57 \\
\hline Toplam & 108,69 & 79,38 & 28,36 \\
\hline \multicolumn{4}{|l|}{ Yillık Toplam Hane halkı Geliri } \\
\hline$<20,000$ Euro & 100,63 & 74,96 & 25,00 \\
\hline $20,000-30,000$ & 108,29 & 82,31 & 24,97 \\
\hline $30,001-40,000$ & 106,39 & 76,80 & 29,25 \\
\hline $40,001-50,000$ & 118,00 & 91,21 & 26,37 \\
\hline $50,001-60,000$ & 130,34 & 91,99 & 37,88 \\
\hline$>60,000$ & 110,19 & 80,93 & 28,45 \\
\hline Toplam & 108,22 & 77,23 & 29,54 \\
\hline
\end{tabular}

\section{Zanzibar'da Yapılan Turist Harcamalarının Analizi}

Otel dışında yapılan turizm harcamalarına ilişkin bilgiler yedi başlık altında gruplandırılarak değerlendirilmeye tabi tutulmuştur. Bunlar; 1) restoran, cafe ve bar harcamaları 2) eğlence ve spor aktivitelerine yönelik harcamalar 3) araba kiralama 4) toplu taşıma harcamaları 5) iletişim harcamaları 6) perakende satış harcamaları (Hediyelik eşya, alışveriş, hatıra eşya) ve 7) diğer harcamalardır. Bu kategorilere göre ziyaretçilerin yaptıkları harcamalar Tablo 8'de özetlenmiştir. Verilen cevapların doğruluğu her ne kadar tartışılır olsa da bu cevaplardan yola çıkarak anklav tur kapsamında yapılan harcama miktarlarının belirlenmesine ışık tutulması açısından önem taşıdığı söylenebilir. Anklav tur ile gelen ziyaretçilerin tesis dişında da harcama yapmalarına rağmen farklı kategorilerdeki otel dışı harcamalardaki düşüşün de hesaplanmasına gerek duyulmaktadır. Verilen cevaplar incelendiğinde; ziyaretçilerin harcamalarının daha çok cafe, bar ve restoranlara veya eğlence ve spor aktivitelerine yönelik olarak gerçekleştirildiği görülmektedir. Bu harcamalar, otel dışı harcamaların \%60'a yakınını oluşturmaktadır.

Geliş ülkesinde ulaşım ve konaklama harcamalarını yapan ziyaretçilerin restoran, cafe, bar, eğlence, sportif harcamaları ve toplu taşıma harcamaları bakımından da en fazla harcama yapan grup oldukları görülmektedir. 
Wineaster Anderson / Türkçeye Çevirenler: Reyhan Bostancı ve Orkhan Alili

Tablo 8. Tek Yön ANOVA sonuçları

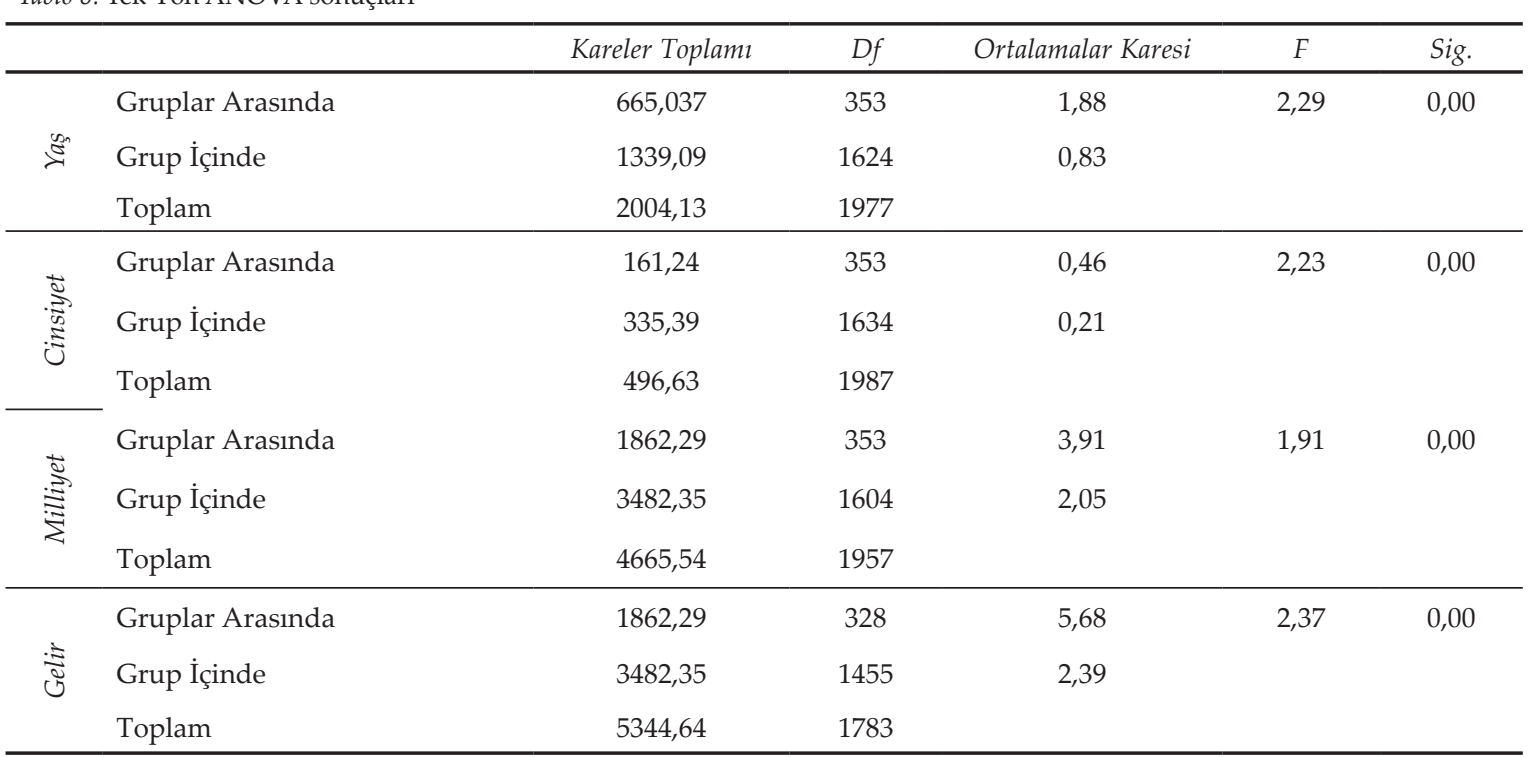

\section{SONUÇ VE ÖNERILER}

Bu çalışmanın amacı Anklav Turizmin gelişen destinasyonlar üzerindeki sosyo-ekonomik etkilerini incelemektir. Araştırma ile turistler tarafından Zanzibar'da yapilan toplam harcama miktarları belirlenmiş, turist harcamaları ve turistlerin sosyo-demografik özellikleri arasındaki ilişkiler saptanarak, gelişen ülkelere yönelik yapılan seyahatlerde seçilen paket tur çeşidi ile yapılan harcamalar arasında istatistiksel olarak anlamlı bir farkın olup olmadığı tespit edilmiştir. Veriler Zanzibar Havalimanı'nda bulunan yabancı ziyaretçilerden toplanmıştır.

Gelişmekte olan ülkelerde yetersiz altyapı, yeni turistik ürün geliştirmede başarısızlık, turizm planlanması ve turizm politikalarının geliştirilmesinde yetersizlikler, pazarlama araştırmalarının yetersizliği, sektörün yerel ekonomi ile doğru bir şekilde bütünleşememesi, kurumsal ve teknik kapasite zayıflı̆̆ı, yetenekli personel bulmanın zorluğu gibi olumsuzluklar turizm sektörünün en çok karşılaştığı sıkıntılar arasında yer almaktadır. Ziyaretçilerin farklı kültürleri tanımasına fırsat sağlayan, seyahat sırasında güvenli olmayan ulaşım araçlarının kullanıldı ğı ve hijyen, emniyet ve güvenlik bakımından da belirsiz özellikler taşıyan ve bu bakımdan çoğunlukla gelişmekte olan ülkelere yönelik olarak gerçekleştirilen anklav turlara yönelik ilginin hızla arttığı görülmektedir. Arz açısından değerlendirildiğinde ise özellikle gelişmiş ülkelerdeki büyük tur operatörlerinin kitle turizmine katılan turistleri çekmek amacıyla anklav turlara yöneldikleri ve bunun tur operatörlerinin ölçek ekonomisine ulaşmalarına da yardımcı olduğu görülmektedir. Oluşturulan paket turlar ile çok sayıda farklı hizmetler bir bütün olarak turistlere sunulmaya çalışılmaktadır. Paket tur için ödenen fiyatın tatil bileşenlerinin ayrı ayrı satın alınması durumunda ödenecek fiyattan çok daha ucuz olması, paket turları satın alan turistler için de büyük ölçüde ekonomik avantajlar sunacaktır. Destinasyon açısından değerlendirildiğinde ise paket turların destinasyonlara değer katacağı düşünülmektedir. Zanzibar'daki Anklav Turizm örneğine baktığımızda, destinasyondaki şartlardan dolayı turistlerin bu turizm türünü tercih ettiklerini söylemek çok da mümkün görünmemektedir, çünkü gelişmekte olan ülkeler arasında çok az destinasyon Zanzibar kadar gelişmiş turistik altyapıya sahiptir. Anklav Turizme en yakın seçenek olarak görülen tam pansiyonun son yillarda beklenen ilgiyi görememesinden dolayı, Anklav Turizmin bir fiyat stratejisi olarak ortaya çıktığını söylemek mümkündür. 
Eğer Anklav Turizm bir fiyatlandırma stratejisi olarak görülüyorsa bunun, diğer satın almalara göre anklav tur ile gelen turistlerin yaptıkları harcamalara da yansıması gerekmektedir. Araştırma sonucunda ortaya çıan verilerde, Zanzibar'da ortalama kalış süresinin 9,32 gün olduğu ve seyahat partilerinin yaklaşık olarak dört kişiden oluştuğu görülmektedir. Genel olarak turistlerin yaptıkları ortalama toplam harcama 119,09 dolar iken, geliş ülkesinde ortalama harcamaların 79,76 dolar, Zanzibar'da yapilan ortalama harcamaların ise 28,92 dolar olduğu görülmektedir. Beklendiği üzere, anklav turlar ile gelen turistlerin geliş ülkesinde daha fazla harcama yaptıkları ortaya çıkmıştır. Bunun yanında, araştırma kapsamında yapılan ANOVA ile seçilen tur türünün turistlerin hem geliş ülkesinde hem de destinasyonda yaptıkları harcamalar üzerinde anlamlı bir etkiye sahip olduğu da ortaya çıkmıştır. Buna göre, anklav turu tercih eden turistler ihtiyaç duydukları tüm hizmetleri geliş ülkesinde satın aldıklarından dolayı Zanzibar'da daha az harcama yapmaktadirlar.

Araştırma sonucunda ortaya çıkan ilgi çekici bulgulardan bir diğeri yaşın artması ile birlikte destinasyonda yapılan harcamaların azalmasıdır. Bu bakımdan, genç ziyaretçilerin yaşça büyük diğer ziyaretçilere göre destinasyonda daha çok harcama yapmaya istekli oldukları görülmektedir. Bunun temel sebebi ise genç ziyaretçilerin destinasyondaki etkinliklere; eğlence aktivitelerine, spor etkinliklerine ve gece hayatına daha aktif katılım sağlamasıdır. Cinsiyet kategorisine göre yapılan analizde ise hem geliş ülkesinde ve destinasyonda yapılan harcamalar açısından, hem de bu iki kalemin toplamında erkeklerin kadınlara göre daha fazla harcama yaptıkları görülmektedir. Araştırma kapsamında harcama davranışları incelenirken turistlerin yıllık toplam hane halkı gelirleri göz önünde bulundurmadan yorumlanmaya çalışılmıştır. Ancak yine de yapılan ANOVA bu dört kategorik değişkenin (yaş, cinsiyet, milliyet ve gelirin) turistlerin destinasyondaki harcamaları üzerinde anlamlı bir etkiye sahip olduğunu ortaya koymaktadır.

Bu çalışma, destinasyondaki paydaşların turizm sektörünün başarılı bir şekilde gelişmesi ve eko- nominin temel sektörlerinden biri haline getirilmesi için kararlılık göstermelerinin önemine dikkat çekme ile beraber bunun da turizmin döviz getirme, yeni istihdam alanları yaratma, yerel ekonomiyi canlandırma ve ekonomiyi çeşitlendirme ile mümkün olabileceğine vurgu yapmaktadır. Bunu gerçekleştirmek ve turizm harcamalarının destinasyonda kalmasını sağlamak amacıyla turizm paydaşları arasında iletişimin sağlanması ve bununla da "Aşağıya damlama Etkisi" ile (trickle-downeffect) bu etkinin toplumun tüm katmanlarına yayılması sağlanmalıdır. Gelecek çalışmalarda; anklav sistemini uygulayan konaklama işletmelerinin incelenmesi; bu işletmelerin Zanzibar'ın turizm sistemi ile olan bağlantısı ve bunun ekonomik sızıntılar üzerindeki etkileri incelenebilir.

\section{KAYNAKÇA}

Abdool, A. ve Carey, B. (2004). Making Enclave More Inclusive: A Research Project on The Economic Impact of The Enclave Hotel Sector in Tobago. UK: The Travel Foundation.

Aguilo', E. ve Juaneda, C. (2000). Tourist Expenditure for Mass Tourism Markets, Annals of Tourism Research, 27 (3): 624-637.

Alegre, J. ve Pou, L. (2006). El Paquete Turístico De Todo Incluido: Un Análisis De Sus Implicaciones Económicas Para El Caso De Las Islas Baleares. Proyecto SEC2002-0512, Ministerio De Ciencia Y Tecnología. Departamento De Economía Aplicada Universitat De Les Illes Balears.

Anderson, W. (2008). Analysis of Enclave Travel Mode: Demand and Supply Perspectives in The Balearic Islands. (Basilmamiş Doktora Tezi). Palme De Mallorca: Balearic Islands Üniversitesi.

Anderson, W. (2010). Determinants of Enclave Travel Expenditure, Tourism Review, 65 (3): 4-15.

Anderson, W., Juaneda, C. ve Sastre, F. (2009). Influences of Pro-Enclave Travel Decisions, Tourism Review, 64 (2): 4-18.

Ashley, C. (2006). Participation by the Poor in Luang Prabang Tourism Economy: Current Earnings and Opportunities for Expansion. Working Paper 273. Londra: Overseas Development Institute.

Enoch, Y. (1996). Contents of Tour Packages: A Cross-Cultural Comparison, Annals of Tourism Research, 23: 599-616.

Freitag, T. (1994). Enclave Tourism Development: For Whom The Benefits Roll?, Annals of Tourism Research, 21(2): 538-554.

Heung, V. ve Chu, R. (2000). Important Factors Affecting Hong Kong Consumers' Choice of A Travel Agency For AI Package Tours, Journal of Travel Research, 39: 52-59.

Holloway, C. (1998). The Business of Tourism. Singapur: Addison Wesley-Longman. 
Holloway, J. (2000). Tour. İçinde J. Jafari (Editör), The Encyclopedia Of Tourism (ss. 582-583). London: Routledge.

Issa, J. ve Jayawardena, C. (2003). The 'AI' concept in the Caribbean, International Journal of Contemporary Hospitality Management, 15 (3): 167-171.

Jang, S., Bai, B., Hong, G. ve O'Leary, J. (2004). Understanding Travel Expenditure Patterns: A Study of Japanese Pleasure Travellers to the US by Income Level, Tourism Management, 25: 331-341.

Kar-ammel, S. ve Lengefeld, K. (2005). Can All-Inclusive Tourism Be Pro-Poor?, http://www.id21. org/insights/insights62/art05.html.

Kastenholz, E. (2005). Analysis of Determinants of Visitor Spending for the Rural Tourist Market In North Portugal, Tourism Economics, 11(4): 555-569.

Mbaiwa, J. (2005). Enclave Tourism and Its Socio-Economic Impact in the Okavango Delta, Botswana, Tourism Management, 26: 157-172.

Meyer, D. (2006). Caribbean Tourism, Local Sourcing and Enterprise Development: Review of The Literature, http://www. propoortourism.org.uk/18_domrep.pdf.

Meyer, D. (2010). Changing Power Relations: Foreign Direct Investment in Zanzibar. İçinde J. Modesale (Editör), Political Economy of Tourism: A Critical Perspective Contemporary Geographies of Leisure. Tourism and Mobility.: Routledge.

Middleton, V. (1994). Marketing in Travel and Tourism. Oxford: Butterworth Heinemann.

Millington, K., Locke, T. ve Locke, A. (2001). The AI market Travel \& Tourism Intelligence. London: Mintel International Group.

Mitchell, J. (2006). Can Tourism Reduce Poverty in Africa? UK: ODI Briefing Paper.

Mitchell, J.ve Page, S. (2005). Linkages and Leakages., Local Supply and Imports, http://www.id21. org/insights/insights62/art04.html.

Mok, C. ve Iverson, T. (2000). Expenditure-Based Segmentation: Taiwanese Tourists to Gaum, Tourism Management, 21(3): 299-305.

Mudambi, R. ve Baum, T. (1997). Strategic Segmentation: An Empirical Analysis of Tourism Expenditure in Turkey, Journal of Travel Research, 36(1): 29-34.
Paris, J. ve Zona-Paris, C. (1999). 100 best AI resorts of the world. Guilford. CT: The Globe Pequot Press.

Peerapatdit, N. (1999). The Impact of Selected Socio-Demographic, Travel-Related and Psychographic Variables on Travel Expenditure (Basılmamış Yüksek Lisans Tezi). Florida: Central Üniversitesi Rosen College of Hospitality Management.

Philips, R. ve Webster, S. (1983). Group travel. NY: Van Nostrand Reinhold.

Reid, A. (1992). Reflections: Waiting for Colombus, The New Yorker, 24 Şubat: 57-75.

Rewtrakunphaiboon, W. ve Oppewal, H. (2004). Holiday Packaging and Tourist Decision Making, Tourism Analysis, 8 (2-4): 193-196

Sheldon, P. (1990). A Review of Tourism Expenditure Research. İçinde C. Cooper (Editör), Progress in Tourism, Recreation and Hospitality Management (ss. 28-29). Londra: Belhaven Press.

Sheldon, P. ve Mak, J. (1987). The Demand for Package Tours: A Mode Choice Modal, Journal of Travel Research, 25 (3): 13-17.

Steck, B., Wood, K. ve Bishop, J. (2010). Tourism More Value for Zanzibar: Value Chain Analysis: Final Report. Zanzibar: VSO, SNV and ZATI.

The Zanzibar Association of Tourism Investors (2009). Progress Report. Membership, Tourism Arrivals, The Activities of ZATI October 2008-October 2009. The Visitor Exit Survey And The Forward View For 2010. Prepared for The ZATI Annual General Meeting.

Tourism Intelligence International (2005). How The British Will Travel 2005. Bielefeld: Tourism Intelligence International.

United Nations (1994). Department for Economic and Social Information and Policy Analysis and World Tourism Organization (WTO) (1994). Recommendations on Tourism Statistics. New York: United Nations.

Wong, S. ve Lau, E. (2001). Understanding the Behavior of Hong Kong Chinese Tourists on Group Tour Packages, Journal of Travel Research, 40: 57-67.

WTO (2005). Basic References on Tourism Statistics. Madrid: World Tourism Organization.

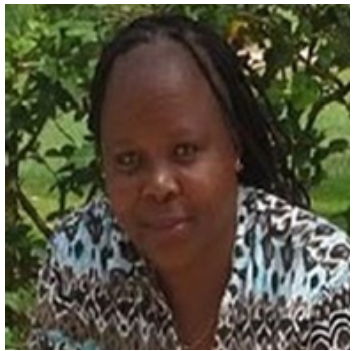

\section{Wineaster ANDERSON}

Uluslararası işletme ve ticaret, turizmde inovasyon ve sürdürülebilirlik, yoksullukla mücadelede küreselleşme gibi alanlarda çalışmalar yapan yazar, Tanzanya Dar es Salaam Üniversitesinde öğretim üyesidir. Tanzanya Doğal Kaynaklar ve Turizm Bakanlığı, Tanzanya Yatırım Ajansı gibi kurumlarda görev yapan yazar, ayrıca İşletme Eğitimi Enstitüsü Yönetim Kurulu üyesidir. 


\section{Türkçeye Çevirenler:}

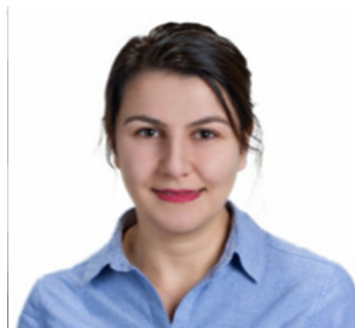

\section{Reyhan BOSTANCI}

2014 yılında Düzce Üniversitesi Turizm İşletmeciliği Turizm İşletmeciliği ve Otelcilik Bölümünde turizm eğitimini tamamlamıștır. 2014 yılında İstanbul Üniversitesi, Turizm İşletmeciliği ABD'de yüksek lisans eğitimine başlamış 2017 yılında eğitimini tamamlamıştır.2017 yılı mayıs ayında Yalova Üniversitesi Armutlu Meslek Yüksekokulu Otel ve İkram Hizmetleri bölümüne Öğretim Görevlisi olarak atanmıştır. Yazar, aynı yılda İstanbul Üniversitesi, Turizm İşletmeciliği ABD'de doktora eğitimine başlamış ve halen aynı kurumda doktora eğitimine devam etmektedir.

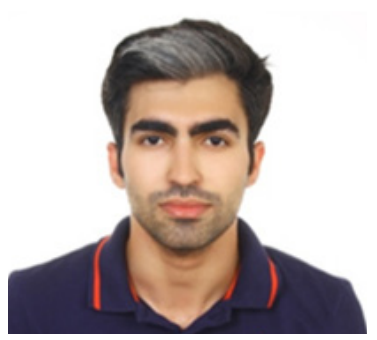

\section{Reyhan BOSTANCI}

2014 yılında Düzce Üniversitesi Turizm İșletmeciliği Turizm İșletmeciliği ve Otelcilik Bölümünde turizm eğitimini tamamlamıştır. 2014 yılında İstanbul Üniversitesi, Turizm İşletmeciliği ABD'de yüksek lisans eğitimine başlamış 2017 yılında eğitimini tamamlamıștır.2017 yılı mayıs ayında Yalova Üniversitesi Armutlu Meslek Yüksekokulu Otel ve İkram Hizmetleri bölümüne Öğretim Görevlisi olarak atanmıștır. Yazar, aynı yılda İstanbul Üniversitesi, Turizm İşletmeciliği ABD’de doktora eğitimine başlamış ve halen aynı kurumda doktora eğitimine devam etmektedir. 